\title{
ŹRÓDŁA DO REKONSTRUKCJI BIBLIOTEKI ZAŁUSKICH
}

Slownik Języka Polskiego (t. 3, Warszawa, 1981, s. 39) określa rekonstrukcję jako „odtworzenie czegoś na podstawie dochowanych fragmentów, szczątków, przekazów, form pochodnych itp., zwłaszcza: odbudowanie, odtworzenie na takich podstawach zniszczonych, częściowo lub całkowicie, budynków albo dzieł sztuki". Jako taka rekonstrukcja oznacza wiele różnych czynności, zależnie od tego, co się odtwarza (zabytkowe budowle, teksty literackie itd.), na podstawie ilu i jakiego rodzaju fragmentów lub przekazów, czy przywraca się pierwotną postać zniszczonego dziela, czy też tworzy jego uproszczony model (odwzorowanie, opis budowy, spis zawartości itd.). Problematyka rekonstrukcji jest stale obecna w pracach m.in. historyków sztuki ${ }^{1} i$ historyków literatury ${ }^{2}$. Często próby rekonstrukcji zbiorów podejmują historycy archiwów ${ }^{3} \mathrm{i}$ historycy bibliotek ${ }^{4}$.

Do szczególnie trudnych należy odtworzenie stanu posiadania największej i najważniejszej z bibliotek staropolskich - Biblioteki Załuskich; powodem jest jej wielkość i rozproszenie, a także liczba i różnorodność źródeł rekonstrukcji.

Zadanie, jakie stawia sobie autor, jest skromne. Nie przedstawiam tu, naturalnie, spisu zawartości księgozbioru, nie podaję nawet pełnej listy źrodeł rekonstrukcji; taka lista, wzbogacona o komentarz zawierający charakterystykę i ocenę wartości każdego źródła, z pewnością potrzebna, przerosłaby ramy artykułu, a ponadto powtarzałaby często materiał zawarty $w$ wielu drukowanych opracowaniach. W niniejszej pracy chodzi mi o to, aby przedstawić wszystkie rodzaje źródet pozwalających na odtworzenie księgozbioru Załuskich, bez względu na sposób ich zapisu (druk, rękopis), okoliczności oraz czas ich powstania (okres Bilblioteki Załuskich, biblioteki cesarskiej w Petersburgu, Biblioteki Narodowej). Celem, jaki sobie stawiam, jest przede wszystkim zebranie i uporządkowanie istniejącej wiedzy; przy tym opisuję też kilka źródeł nieznanych historykom.

Jak wiadomo, druki i rękopisy Załuskich udostępnione publiczności w roku 1747 zostały z nakazu Katarzyny Wielkiej przewiezione w $1796 \mathrm{r}$. jako łup wojenny do Petersburga, gdzie na ich fundamencie otwarto w roku 1814 Cesarską Bibliotekę Publiczną (dziś Biblioteka Państwowa im. M.J. Sałtykowa-Szczedrina). Na mocy traktatu ryskiego część druków i większość rękopisów wróciła do Warszawy w latach 1923-1934 i stała się podwaliną utworzonej w roku 1928 Biblioteki Narodowej; większość rewindykatów uległa zagładzie w roku 1944. Nie wiadomo dokładnie, ile druków i rękopisów miała Ksiażnica, gdyż zbiory policzono dopiero w Petersburgu. Wyniki dwukrotnych wyliczeń były podobne; G. Bogdanow (1796) doliczył się 383140 druków, a M.J. Antonowski (1806) - 379 538; Antonowski 
określił liczbę rękopisów na 10 425, a eksperci rewidykacyjni (w latach 1922-1934) na ponad 11 tys. (choć zaznaczyli przy tym, że są to dane minimalne, gdyż po 130 latach od konfiskaty nie zawsze da się ustalić proweniencję rękopisu). Nie wszystkie zbiory (przeszło 400 tys. vol. druków, ok. 12 tys. rękopisów) przewieziono do stolicy imperium rosyjskiego i nie wszystkie znalazły się na powrót w kraju; w zajętej przez trzy mocarstwa Polsce pozostała w XVIII w. pewna część druków, których liczbę trudno określić, a w mieście nad Newą w wieku XX - większość druków i pewna, też trudna dziś do określenia, liczba rękopisów. Zbiory Załuskich, głównie druki, dość znacznie uszczuplono i rozproszono w czasie pakowania, przewozu i w pierwszych dziesięcioleciach składowania w Petersburgu. Stało się tak wskutek zaniedbań, świadomego niszczenia, sprzedaży na aukcjach, darowizn. Część druków powróciła do kraju nie na mocy traktatu ryskiego, ale wcześniej, w latach 1840-1842 i 1862, jako dary cara. Z ok. 14 tys. rękopisów rewindykowanych, z których większość pochodziła z Biblioteki Załuskich, niektóre (m.in. 1825 w Bibliotece Narodowej i 26 w AGAD) - ocalaty ${ }^{5}$.

\section{DRUKI}

\section{Rękopiśmienne katalogi druków (okres Biblioteki Załuskich)}

W XVIII w. sporządzono bliskę setkę rękopiśmiennych katalogów lub spisów części bądź całości zbiorów Józefa i Andrzeja Załuskich oraz Książnicy Warszawskiej. W początku lat 1760 , gdy było ich ponad 50 , opracowano ich spis, który włączono do książki J.D. Janockiego Bibliographia Zalusciana, Berdyczów-Warszawa 1763-1766. Spis zawierał 53 pozycje (numery 234-287 działu Bibliotheca Zalusciana manuscripta, s. 349-352 i nosił tytuł Cathalogi Bibliothecae meae inservientes). Oprócz katalogów ogólnych i cząstkowych obejmował też m.in. listy dubletów, a nawet katalogi innych księgozbiorów. Spis ten (a dokladniej, jego 44 pozycje) ogłosił w roku 1861 w tłumaczeniu francuskim Rudolf Minzloff w Catalogue des publications de la Biblioteque Imperiale de Saint-Petersburg, s. XLIII-LI ${ }^{6}$. Wkrótce po publikacji w Bibliographia Zalusciana... spis stracił aktualność, gdyż w Książnicy sporządzono kolejne katalogi?

Warto zwrócić uwagę, że oprócz wykazów katalogów powstawały w bibliotece przewodniki po księgozbiorze; począwszy od rozkładu książek z lat 1729 i 1732, poprzez Tytuly księgarni publicznej Załuskiej i Xięgarnię encyklopedyczną najlepszych w każdej materii autorów na 25 szaf podzieloną, zredagowane po inauguracji Książnicy, aż po informacje opracowane w latach, gdy pozostawała ona pod zarządem KEN ${ }^{8}$.

Powstawanie kolejnych katalogów dokumentują liczne, pozostawione w rękopisach bądź opublikowane źródła ${ }^{9}$. Po wojnie katalogi stały się przedmiotem zainteresowania kilku historyków ${ }^{10}$.

Rewindykowane na mocy traktatu ryskiego, niemal wszystkie katalogi spłonęły w październiku 1944 r. Ocalały dwa wyciągi z katalogów - dzieł anonimowych (ok. 1728, B.N. sygn. II 3139, poz. 6) i judaików (1759, B.N. II 3208), Catalogus universalis scriptorum poeticarum polono idiomate exartorum (Sachsischelan- 
desbibliothek Drezno, Codex Mscr. Dresd., C 3429, 1731 r.), Catalogues des livres doubles de la Biblioteque de Luneville (Biblioteka Polska w Paryżu, sygn. 204, mikrofilm w B.N. A 1063, ok. 1741 r.), a także rozmaite robocze spisy wydawnictw kupionych lub do kupienia ${ }^{11}$.

Najważniejsze źródła zawierające opisy zniszczonych katalogów to:

1) katalog rękopisów opracowany w latach 1806-1807 pod kierunkiem Piotra Dubrowskiego, Biblioteka im. Saltykowa-Szczedrina (skrót: B S-Sz.) w Petersburgu, sygn. Razn. F XVIII nr 174;

2) katalog rękopisów Cesarskiej Biblioteki Publicznej, B S-Sz., mikr. B.N. A 216, A 265;

3) Cytowany w przyp. 6 katalog R. Minzloffa;

4) Ksiażka A. Kaweckiej-Gryczowej, cytowana w przyp. 7.

Wymienione tu źródła notują ok. 70 katalogów druków, ogólnych (12) i cząstkowych. Cząstkowe opisują dzieła o wspólnej proweniencji (biblioteka żółkiewska, księgozbiór A.S. Załuskiego, biblioteka lunewilska) lub dzieła określonego gatunku piśmiennictwa, dziedziny wiedzy, języka i formatu, względnie też wydawnictwa odznaczające się wybraną cechą, jak radkość czy użyteczność.

\section{Drukowane katalogi druków (okres Biblioteki Załuskich)}

Drukowane katalogi druków możnaby podzielić na trzy grupy.

1) Katalogi opublikowane dla prezentacji zasobów Książnicy Załuskich. Pierwszą publikacją tego typu był Specimen catalogi bibliothacae Josephi Zaluski [w:] Józef Andrzej Załuski, Programma litterarium ad bibliophilos..., Warszawa 1732 (omówiono 331 dzief). Broszurę tę, w której przedstawiono zamiar otwarcia dla publiczności połączonych zbiorów obu braci Załuskich, wznowiono w Gdańsku w latach 1743 i 1753. Następnie, w latach 1747-1753 J.D. Janocki opublikował w Dreźnie w pięciu tomach katalog pt. Nachricht von denen in der Hochgraflich Zaluskischen Bibliothek sich befindenden raren Buechern.

2) Spisy piśmiennictwa oparte na zbiorach Książnicy, m.in. Contenta collectionis scriptorum ecclesiasticorum Poloniae ineditorum vel rarissime obviorum [w:] J.A. Załuski, Conspectus Novae Collectionis Legum Ecclesiasticarum Poloniae, 1744 (673 pozycji, z czego 639 druków); spis 46 edycji Szkoły Salerneńskiej w pracy J.D. Zaluskiego pt. Apteka dla tych, co jej ani lekarza nie mają, Warszawa 1750.

3) Katalogi dubletów Ksiażnicy Zaluskich. Rejestrowali je: R. Minzloff, Estreicherowie, J. Rudnicka i W. Tyszkowski ${ }^{12}$; byly one też przedmiotem rozprawy M. Manteufflowej ${ }^{13}$.

W ostatnich latach odkryto nieznane lub zagubione pozycje. Ewa Zwinogrodzka odszukała opisany w ostatnim tomie Estreichera (t. 34, s. 241) i uznany za zaginiony katalog $\mathrm{z}$ roku $1762^{14}$; autor tego artykulu odkrył w petersburskiej Bibliotece im. Saftykowa-Szczedrina trzy klocki ze współoprawnymi katalogami. Katalogi te pochodzą z samej Biblioteki Zaluskich; są wśród nich egzemplarze unikatowe.

Po tych odkryciach bibliotecznych listę katalogów dubletów J. Rudnickiej warto uzupełnić o następujące dane: 
Catalogus librorum duplicatorum magna ex parte rariorum Bibliothecae Publicae Varsaviensis, Warszawa, Drukarnia Mitlerowska, 1760, BS-Sz. sygn. Kc 1823.

Catalogus librorum duplicatorum Bibliothecae Publicae Varsaviensis, Warszawa, Drukrania Mitlerowska, 1761, B.U.W. sygn. 28. 20. 4. 3359.

Catalogus librorum duplicatorum Bibliothecae Publicae Zaluscianae qui lege auctionis dividentur, Warszawa, brak nazwy drukarni, 1762, BJ bez sygn. (s. 1-16); B S-Sz. sygn Kc 1823 (s. 1-4), egzemplarz z ręcznymi oznaczeniami cen.

Catalogus librorum duplicatorum Bibliothecae Publicae Zaluscianae qui proximis mensibus auctionis lege dividentur, Warszawa, brak nazwy drukarni, 1765, B S-Sz. sygn. Kc 1824.

Catalogus omnis generis librorum duplicatorum, qui ex Zalusiciana Varsaviensi Reipublicae Bibliotheca, ubi minus necessarii atque utiles sunt, auctionis jure ac praestante pecunis, aliorum usibus concedentur, Warszawa, Drukarnia Groella, 1781, B S-Sz. sygn. Kc 1825.

Druczek pt. Catalogus omnis generis librorum duplicatorum..., Warszawa 1781, opisany przez J. Rudnicką pod $\mathrm{nr} 41$, miał dwa suplementy, opublikowane w roku 1782 pt. Continuatio catalogi omnis generis. Znane jedynie $z$ lakonicznych wzmianek w Gazecie Warszawskiej (23 X 1782) Bibliografii Estreicherów, opisane przez J. Rudnicką pod nr 42, znajdują się one w B S-Sz. sygn. Kc 1825 (jeden z nich zawiera 1-86, a drugi 1-186 strọn).

Katalogi dubletów z Petersburga zasługiwałyby na szczegółowe porównanie z egzemplarzami zachowanymi w Polsce ${ }^{15}$.

\section{Rękopiśmienne katalogi druków (okres Cesarskiej Biblioteki Publicznej)}

Wg Księgi Jubileuszowej Cesarskiej Biblioteki Publicznej są to: skrótowy inwentarz spisany po przewiezieniu Biblioteki do Petersburga (bez informacji o miejscu i roku wydania opisywanych pozycji) oraz kolejne katalogi, w których zaznaczono pochodzenie książek ${ }^{16}$. Problem wymaga zbadania $w$ archiwum biblioteki im. Saltykowa-Szczedrina.

\section{Drukowane katalogi druków (okres Cesarskiej Biblioteki Publicznej)}

Źródłem wielu wiadomości o drukach Biblioteki Załuskich są też drukowane katalogi Cesarskiej Biblioteki Publicznej (o ile zaznaczają proweniencję opisywanych dzieł). Spis tych katalogów zawierają m.in. 'następujące opracowania: Gosudarstwiennaja Publicznaja Biblioteka im. M.E. Sałtykowa-Szczedrina. Bibliograficzeskij ukazatiel. Leningrad 1989, s. 131-146; E. Chwalewik, Losy zbiorów $w$ Rosyjskiej Bibliotece Publicznej w Leningradzie, Warszawa-Kraków 1926, s. 39-43; A. Ha!ban [A. Blumenstock], Z bibliotek rosyjskich, z. 1, Kraków 1898; Dokumenty dotyczące akcji delegacji polskiej w komisjach mieszanych reewakuacyjnej i specjalnej w Moskwie, z. 8, Warszawa 1923, s. 163. Dodatkowo wspomnieć trzeba o artykule Spektatora [S. Lisowskiego], Notatka o prowe- 
niencji inkunabułów, znajdujących się w Rosyjskiej Publicznej Bibliotece w Piotrogradzie, „Przewodnik Bibliograficzny” 1926 nr 6, s. 267-268.

\section{Dokumenty $\mathrm{z}$ archiwum bibliotecznego (XVIII-XX w.)}

Kolejnym źródłem do odtworzenia zbioru druków Biblioteki Publicznej są dokumenty jej działalności (od XIX w. zwyczajowo włączane do archiwów bibliotecznych), takie jak korespondencja z księgarzami, oferty i rachunki księgarskie, spisy darów ksiażkowych, rewersy i odpowiedzi na kwerendy czytelników. Tego rodzaju dokumenty znajdują się obecnie w dwóch zbiorach: w Bibliotece im. Saltykowa-Szczedrina w pudłach oznaczonych nazwą Archiv Załuskich oraz w Bibliotece Narodowej w tomach korespondencji Załuskich (sygn. III 3220 do III 3269) oraz w teczkach opatrzonych sygnaturą II 4688 i II 4689. Zawartość archiwum Załuskich oraz znaczenie korespondencji Załuskich omówił B.S. Kupśćc ${ }^{17}$. Teczki, nieznane historykom, nie zostały dotąd zinwentaryzowane.

Warto tu dodać, że w Bibliotece Uniwersytetu Warszawskiego zachowały się katalogi aukcyjne ze zbiorów Załuskich z odręcznymi zapiskami referendarza koronnego dotyczącymi pozycji do kupienia ${ }^{18}$.

\section{Publikacje naukowe (XVIII-XX w.)}

Źródłem informacji o drukach, które wchodziły do księgozbioru Biblioteki są też publikacje J.A. Załuskiego i J.D. Janockiego. Książnica Warszawska była warsztatem pracy obu uczonych i wobec tego można z dużym prawdopodobieństwem uznać, że w swych opracowaniach cytowali oni lub omawiali przede wszystkim te dziela, które znajdowali pod ręką; nie było zresztą w kraju konkurencyjnego księgozbioru. Wymieńmy tu takie wydawnictwa, jak J.A. Załuskiego Specimen historiae Polonae criticae, Warszawa 1735, zawierający spis cytowanych prac, Centuria scriptorum diaeticorum, umieszczona w Aptece dla tych, co jej ani lekarza nie mają, Warszawa 1750, czy J.D. Janockiego Lexicon derer itztebenden Gelehrten in Polen, t. 1-2, Warszawa 1755 lub Janociana sive clarorum atque illustrium Poloniae virorum, t. 1-2, Warszawa 1776-1779, t. 3 wyd. S.B. Linde, Warszawa 1819. Nieraz obaj uczeni zaznaczali, że cytowane książki pochodzą z Biblioteki Załuskich (tak robił m.in. Załuski w Bibliotheca poetarum polonorum... lub Janocki w Janocianach...). Z interesującego nas punktu widzenia duże znaczenie ma pozostawiona w rękopisie J.A. Załuskiego Polska w obszernych swoich wiadomościach skrócona..., a zwlaszcza ta część pracy, którą J. Muczkowski ogłosił w Krakowie w roku 1832 pt. Biblioteka historyków, prawników, polityków i innych autorów polskich lub o Polsce piszących. O poszczególnych drukach znajdujących się w zbiorach Książnicy informują też przedmowy w reedycjach dokonanych przez Załuskiego i Janockiego i uczonych z kręgu Książnicy ${ }^{19}$. Opisy zachowanych egzemplarzy, pochodzących z Biblioteki Załuskich, spotyka się też w dwudziestowiecznym piśmiennictwie historycznym ${ }^{20}$. 


\section{Ogłoszenia o skradzionych egzemplarzach (XVIII w.)}

Za życia Załuskich prasa i czasopisma informowaly nieraz o tytułach cenniejszych dzieł skradzionych z kamienicy daniłowiczowskiej z prośbą o pomoc w ich odzyskaniu ${ }^{21}$.

\section{Druki rozproszone}

Wskutek rozproszenia księgozbioru Załuskich druki z charakterystycznymi znakami proweniencyjnymi Książnicy spotyka się w licznych bibliotekach Rosji i Polski ${ }^{22}$.

\section{RĘKOPISY}

\section{Rękopiśmienne katalogi rękopisów (okres Biblioteki Załuskich)}

Źródla przekazały informacje o następujących rękopiśmiennych katalogów manuskryptów:

1) Catalogus ordine alphabetico cognominum authorum dispositus omnium et singulorum codicum manuscriptorum Bibliothecae Zaluscianae Varsoviensis Publicae J.A. Załuski referendarii Regni, anno MDCCXLVIII calendis Julii conscriptus.

2) Catalogus omnium et singulorum codicum manuscriptorum Zalusciane Bibliothecae ex ipso autographo IIImi Dni J.A.Załuski...per...M.A.Trotz Lipsiae descriptus anno 1757.

Oba katalogi doczekały się wzmianek w literaturze ${ }^{23}$. Jak można sądzić na podstawie uwag S. Turowskiego (1913) i P. Bańkowskiego (1937), którzy oglądali rękopisy Załuskich z autopsji, manuskrypt katalogu z roku 1757 był wersją poprzedniego, przygotowaną jako część zamierzonej publikacji pt. Bibliotheca Polona Magna Universalis. Ostatecznie cząstkę tego katalogu, obejmująca prace J.A. Załuskiego oraz utwory związane z rodziną Załuskich, J.D. Janocki włączył do Bibliographia Zalusciana..., Berdyczów-Warszawa 1763-1766.

Zarówno oba katalogi, jak i jedyne kompletne egzemplarze Bibliographia Zalusciana..., spłonęły w roku 1944.

Ocalał natomiast fragment nieznanego historykom katalogu (w teczce rps. BN sygn. II 4869). Fragment liczy dwie karty; zawiera urywek opisu jednej (oznaczonej numerem 3) oraz opis 10 pozycji ( $n r$ 4-12). W katalogu opisano m.in. rękopisy Kadłubka(2), Długosza(4, kronika i listy), Kurdwanowskiego i Zieleńskiego (Commentatio in Vincentii Kadlubkonis), a także Constitutionis Ecclesiae Poloniae oraz Pandecta medicinalis. Tekst pisany maczkiem, ręką J.D. Janockiego.

Kilkanaście opisów rękopisów zawiera katalog dubletów biblioteki lunewilskiej J.A. Załuskiego ${ }^{24}$.

Jest możliwe, że przynajmniej niektóre ze zniszczonych w czasie wojny katalogów Biblioteki rejestrowały nie tylko druki, ale także - zgodnie z przyjętym wówczas w bibliotekach zwyczajem - manuskrypty. 


\section{Drukowane katalogi rękopisów (okres Biblioteki Załuskich)}

W druku ukazały się następujące katalogi rękopisów kolekcji Załuskich:

1) J.D. Janocki, Specimen catalogi codicum manuscriptorum Bibliothecae Zaluscianae, Drezno 1752 (omawia 500 pozycji).

2) [J.A. Załuski, M.A. Troc], Manuscripta seu catalogus codicum manuscriptorum Bibliothecae J.A. Com. Zaluski... vel ab ipso vel ab aliis Zaluskiis eius affinibus exaratorum et primo eius operata edita, inedita ac praelo parata vel ad fecta scripta aut horum anonimorum quae ipse possident [w:] J.D. Janocki, Bibliographia Zalusciana..., Berdyczów-Warszawa 1763-1766, s. 322-416 (808 poz.).

3) J.D. Janocki, Bibliothecae Zaluscianane codices mms. selectiores de rebus polonicis tractantes [w:] tegoż, Musarum sarmaticarum specimina nova, Warszawa, 1971, s. $82-116$ (131 poz.).

\section{Rękopiśmienne katalogi rękopisów (okres petersburski)}

Odtworzyć stan posiadania Biblioteki Załuskich pozwalają następujące katalogi Cesarskiej Biblioteki Publicznej:

1) Katałog rukopisej BS-Sz. syg. Razn. F XVill nr 174. Opracowany pomiędzy 14 VI 1806 a 18 X 1808. Jest to inwentarz zawartości 46 skrzyń z rękopisami, zawierający opisy 8568 manuskryptów w 11010 woluminach. Sporządzony przez bibliotekarzy cesarskich kawalera d'Augarda, opata de Grandville oraz Piotra Dubrowskiego, pod kierunkiem Dubrowskiego. Opis manuskryptu zawiera: numer pozycji w skrzyni, imię i nazwisko (niekiedy tylko nazwisko) autora, tytuł, format i liczbę woluminów, a także ( $z$ wyjątkiem rękopisów ze skrzyń 1, 2, 4, 31 i33) - dawne sygnatury Biblioteki Załuskich.

2) Luźne kartki katalogowe, spisane przez Piotra Dubrowskiego. Obecnie znajdują się one w dwóch zbiorach, sygn. F 120 nr 1882 oraz w Dziale Zachodnim (bez sygn.). Opis taki, jak w źródle omawianym poprzednio. Dubrowski uwzględnia dawne sygnatury Biblioteki Załuskich.

Oba źródła są jedynymi z najważniejszych dla omawianego problemu. Dotąd nie cytowane w polskiej literaturze ${ }^{25}$.

3) Katalog ksiażkowy, opracowany w latach 1843-1846. Rękopisy opisane w podziale na:

a. języki (m.in. łacińskie, polskie, niemieckie, francuskie, różnojęzyczne);

b. formaty (folio, quarto i octavo);

c. działy reczowe (19, a osobno - Collectio autographorum).

Sygnatura składa się z czterech składników: określenia języka, formatu, numeru działu i numeru pozycji w dziale.

Dział rękopisów w języku polskim znany z wielu XIX w. odpisów ${ }^{26}$. W Bibliotece Narodowej w Warszawie dostępne są mikrofilmy całości działów polskiego (syg. A 216) i łacińskiego (A 265) oraz - z pozostałych działów - kserokopie z opisami rękopisów, które zwrócono Polsce na mocy traktatu ryskiego.

Katalog ma obszerną literaturę przedmiotu ${ }^{27}$. 


\section{Drukowane katalogi rękopisów (okres petersburski)}

Ważnym źródłem informacji o rękopisach Biblioteki Załuskich są też drukowane cząstkowe katalogi lub omówienia zasobów rękopisów Biblioteki Cesarskiej. Spisy tego rodzaju publikacji podaja: Gosudarstwiennaja..., s. 150-195; P. Grimsted-Kennedy, Archives and Manuscript Repositories in the USRR, vol. 1, Moscov and Leningrad, Princeton 1972, s. 305-321 oraz suplement, Switzerland 1976, s. 128-136; P.O. Kristeller, Latin Manuscript Books before 1600, New York 1965, s. 136-138; Biblioteka Narodowa. Katalog rękopisów, ser. 2, t. 2, opr. B.S. Kupść, K. Muszyńska, Warszawa 1980, s. 18-22; P. Bańkowski, Rękopisy rewindykowane przez Polskę z ZSRR na podstawie traktatu ryskiego i ich dotychczasowe opracowania, Kraków 1937; Nowy Korbut, t. 4, s. 101-102, t. 6 cz. 1, s. 525-528; K. Estreicher, Załuscy. Bibliografia odnosząca się do Załuskich z wieku XVII i XVIII, Kraków 1952, s. 303-306; Dokumenty dotyczące akcji delegacji polskiej..., Warszawa 1923, s. 91-100.

Podaną w wyż. wym. książkach literaturę przedmiotu warto uzupełnić o pominięte w nich pozycje ${ }^{28}$.

\section{Rękopiśmienne i drukowane katalogi rękopisów (okres po rewindykacji)}

Listę spisów i katalogów rękopisów Biblioteki Załuskich opracowanych w Warszawie po ich rewindykacji z Rosji (w I. 1923-1934) zamieszczają B.S. Kupść i K. Muszyńska ${ }^{29}$. Listę tę możnaby rozszerzyć o spis prac rękopiśmiennych J.A. Załuskiego (K. Estreicher, Załuscy..., s. 236-268) oraz o następujące materiały niedrukowane:

1) Piotr Bańkowski, Opisy rękopisów Bibl. Nar. z l. 1935-1939. Bruliony, rps. Archiwum PAN w Warszawie, sygn. 2410;

2) Stanisław Bodniak, Opisy rękopisów rewindykowanych. Czystopisy na powielanych formularzach, rps. BN, bez sygn.;

3) Odpis protokótu zaginięcia 99 rękopisów BN w czasie między 1 IX 1939 a 8 VII 1940. [w:] P. Bańkowski, Zasoby Działu Rękopisów BN w r. 1939, jego straty w czasie wojny i problem odszkodowania. Masz. BN nr akc. 3908;

4) Odpis protokółu złożenia dwóch kufrów z rękopisami Bibl. Nar. na przechowanie do skarbca w Banku Gospodarstwa Krajowego w Warszawie w dn. 5 VIII 1939 [w:] P. Bańkowski, Zasoby...

Ważne znaczenie ma nadal kartoteka zniszczonych rękopisów Bibl. Nar., zawierająca informacje ustalone na podstawie różnych materiałów. Podaje ona opisy w układzie katalogu petersburskiego z I. 1843-1846. Kartoteka nie uwzględnia opisów zawartych w omówionych wcześniej' dziewiętnastowiecznych inwentarzach i katalogach petersburskich, a także opisów brulionowych $P$. Bańkowskiego. Jej wadą jest też brak indeksów (autorów i tematów oraz chronologicznego i geograficznego).

W Bibliotece Narodowej ocalake manuskrypty Ksiażnicy Warszawskiej mają obecnie (jesień 1991 r.) następujące rodzaje opisów: 
sygn. 3306-3300- polonica, Biblioteka Narodowa. Katalog rękopisów. Ser. 2, t. 2. Opr. B.S. Kupść, K. Muszyńska, Warszawa 1980;

sygn. 3301-3641- rękopisy w językach łacińskim i francuskim, katalog w masz., opr. B.S. Kupść i K. Muszyńska;

sygn. 3642-3780 oraz 4874-4888- rękopisy w językach łacińskim i francuskim, inwentarz akcesyjny;

sygn. 3781-4255- rękopisy w językach niemieckim, katalog mszp., opr. M. Wrede;

sygn. 4255-4873- rękopisy w języku niemieckim, katalog kartkowy, opr. B. Smoleńska.

Wśród rękopisów oznaczonych wymienionymi wyżej sygnaturami, obok egzemplarzy pochodzących z Biblioteki Załuskich (większość) znajdują się także manuskrypty z innych skonfiskowanych zbiorów, przede wszystkim Biblioteki Przyjaciół Nauk i Biblioteki Publicznej przy Uniwersytecie Warszawskim.

\section{Korespondencja biblioteczna (XVIII-XX w.)}

Wiele wiadomości o rękopisach kryje też w sobie korespondencja biblioteczna, zwłaszcza listy z prośbą o udostępnienie wskazanych pozycji, a także - urzędowe dokumenty bibliotek.

Kwerendę w poszukiwaniu tego rodzaju źródel warto przeprowadzić:

a) dla okresu Biblioteki Załuskich - w korespondencji braci Załuskich oraz J.D. Janockiego, znajdującej się w Bibliotece Narodowej oraz w Bibliotece im.Saltykowa-Szczedrina ${ }^{30}$;

b) dla okresu petersburskiego - w korespondencji dyrektora Biblioteki A.F. Byczkowa (zbiory B S-Sz. oraz Archiwum petersburskiego Oddziału Akademii Nauk ZSRR) ${ }^{31}$;

c) dla okresu Biblioteki Narodowej - w jej archiwum ${ }^{32}$.

\section{Apele i memoriały (okres Biblioteki Załuskich)}

Opisy posiadanych manuskryptów znalazły się też w apelach J.A. Załuskiego o pomoc $w$ kompletowaniu księgozbioru, drukowanych $w$ prasie lub $w$ broszu$\operatorname{rach}^{33}$, a wiadomości o zaginionych rękopisach - $w$ memoriałach pisanych $w$ sprawie Biblioteki do Stanisława Augusta oraz władz KEN ${ }^{34}$.

\section{Gazety uczone i inne materiały informacyjne (okres Biblioteki Załuskich)}

Informacje o nowo pozyskanych lub szczególnie cennych rękopisach trafity także w XVIII w. do gazet uczonych, publikacji typu kroniki naukowej oraz relacji z uczonych podróży ${ }^{35}$. 


\section{Publikacje naukowe (okres Biblioteki Załuskich)}

Wiele informacji o rękopisach Biblioteki Załuskich mieszczą w sobie publikacje J.A. Załuskiego, J.D. Janockiego oraz uczonych z ich kreggu. Dla przykładu warto tu przytoczyć Załuskiego Apteka dla tych, co jej ani lekarza nie mają..., Warszawa 1750 (s. 93-94, 113, 125) i Anecdota Jablonoviana.... (s. 252nast.), J.D. Janockiego Polnischer Buechersaal..., cz. 1, Wrocław 1756 i Janociana..., t. 1-2 Warszawa 1776-1779, t. 3 Warszawa 1819 czy prace A. Bremonda, J.G. Boehme, F. Buydeckiego, Ch.G. Friese, O. Kopczyńskiego, W. Muratowicza ${ }^{36}$.

\section{Publikacje naukowe (okres petersburski)}

Wiele wzmianek o rękopisach Biblioteki Załuskich (z zaznaczeniem pochodzenia) zawierają prace historyczne, oparte na źródłach Cesarskiej Biblioteki Publicznej; informacje o autorach i rozprawach cytujących $\mathrm{m}$. in. źródła z Książnicy Warszawskiej podaja P. Bańkowski, A. Blumenstock, E. Chwalewik, M. Dybaczewska, J. Korzeniowski, E. Kuntze, M. Łodyński, J. Róziewicz oraz Dokumenty dotyczące akcji delegacji polskiej... ${ }^{37}$

\section{Publikacje naukowe (okres po rewindykacji)}

Rękopisy Zaluskich służyły autorom licznych prac historycznych, pisanych w dwudziestoleciu międzywojennym oraz po wojnie. Tak jak w przypadku prac XVIII i XIX wiecznych, cytaty źródłowe przytaczane w tekście i przypisach są dziś często jedynym śladem po nieistniejących materiałach ${ }^{38}$.

\section{Materiały warsztatowe uczonych (XVIII-XX w.)}

W cytaty oraz wyciągi i wypisy źródłowe obfitują materialy warsztatowe historyków i filologów. Rękopisy Biblioteki Załuskich znalazły swoje odbicie w spuściźnie rękopiśmiennej m.in. Feliksa Łoyki, Bonawentury Makowskiego i Adama Naruszewicza (zbiory Załuskich w kamienicy daniłowiczowskiej), Mikołaja Malinowskiego, Juliana Bartoszewicza, Augusta Bielowskiego i Stanisława Turowskiego (zbiory Załuskich w Petersburgu) oraz Stanisława Bodniaka, Eugenii Brańskiej, Marii Hornowskiej, Kazimierza Piekarskiego i Władysława Semkowicza (rękopisy Załuskich po rewindykacji); niektóre z w.w. spuścizn zachowaly się do dziś ${ }^{39}$.

\section{Korespondencja uczonych (XVIII-XX w.)}

Innym źródłem, w którym znajdują się wzmianki o manuskryptach Książnicy Warszawskiej, są listy pomiędzy uczonymi (historykami i filologami). W XVIII w. m.in. korespondencja Adama Naruszewicza, w wieku XX - Juliana Krzyżanowskiego $^{40}$. 


\section{Odpisy (XVIII-XX w.)}

Dla odtworzenia stanu posiadania Załuskich dużą wartość mają kopie nie istniejących rękopisów - sporządzone bądź w celach naukowych, bądź kolekcjonerskich. W zbiorach polskich i obcych spotykamy dość liczne tego typu opisy ${ }^{4}{ }^{1}$.

\section{Edycje źródłowe (XVIII-XX w.)}

Dla wiedzy o rękopisach Książnicy Warszawskiej istotne są też edycje materiałów i dokumentów z kolekcji Załuskich. Aparat edytorski, a zwłaszcza przedmowy edytora, zawierają $z$ reguł informacje o pochodzeniu i losach publikowanych źródet ${ }^{42}$.

\section{Rękopisy rozproszone}

Istnieją rękopisy Biblioteki Zaluskich, które nie podzieliły losu większości (Biblioteka Załuskich do roku 1796; petersburska biblioteka cesarska do lat 19231934; Warszawa, początkowo Biblioteka Uniwersytecka, od roku 1928 - Narodowa) tylko - w którymś momencie historii zbioru - zostaly od niego odłączone; bądź pozostały w mieście, które opuściła główna część kolekcji (w Warszawie w roku 1796, w Leningradzie po zakończeniu rewindykacji), bądź też przeszły do innego księgozbioru z bibliotek: Załuskich, Cesarskiej i Narodowej.

W wieku XVIII, jak sądzi S. Grzybowski, niektóre rękopisy Załuskich trafity do Archiwum Stanisława Augusta ${ }^{43}$; pod koniec stulecia pewne manuskrypty opuścily główny zbiór w czasie pakowania, przewozu i rozbijania skrzyń w Petersburgu ${ }^{44}$ wiadomo, że rękopisy zabrali wówczas Litawor Chreptowicz ${ }^{45}$ i Tadeusz Czacki ${ }^{46}$; $w$ stolicy nad Newą uszczuplili kolekcję Żegota Onacewicz ${ }^{47}$ oraz zbieracze rosyjscy Piotr Dubrowski ${ }^{48}$ i hrabia Suchtelen ${ }^{49}$. Większość zbioru umieszczono w gmachu Cesarskiej Biblioteki Publicznej przy ulicy Sadowej, niektóre rękopisy przydzielono innym instytucjom, jak bibliotekom Sztabu Glównego i Akademii Duchownej, a także (przejściowo) Ermitażowi ${ }^{50}$.

Większość rękopisów spłonęła w październiku 1944 r.; czẹść ocalałych uległa rozproszeniu ${ }^{51}$.

Wzmianki o zniszczonych rękopisach zawiera piśmiennictwo dotyczące zagłady bibliotek warszawskich ${ }^{52}$.

Z fragmentów zbioru Załuskich, które w różnych okresach zostały odłączone od korpusu kolekcji, znamy opisy zniszczonych manuskryptów Biblioteki Ordynacji Krasińskich ${ }^{53}$ (ze zbioru $\dot{Z}$. Onacewicza). Interesujące nas rękopisy są dziś w bibliotekach: Czartoryskich ${ }^{54}$ (ze zbioru T. Czackiego), Jagiellońskiej ${ }^{55}$ i Ossolineum $^{56}$ oraz w Archiwum Grównym Akt Dawnych ${ }^{57}$; w Rosji - w Bibliotece im. Sałtykowa-Szczedrina ${ }^{58}$.

\section{Przypisy}

${ }^{1}$ Por. referaty i glosy w dyskusji zamieszczone w książce Oryginał. Replika. Kopia, Warszawa 1971. 
${ }^{2}$ Zob. m.in. T. Zieliński, Rekonstrukcja tragedyj greckich [w:] Szkice antyczne, Kraków 1971, s. 557-575.

${ }^{3}$ M.in. P. Bańkowski, Archiwum Stanisława Augusta, Warszawa 1958; P. Grimsted-Kennedy, Czym jest i czym byla Metryka Litewska, "Kwartalnik Historyczny” 1985, nr 1, s. 55-83; też, Układ i znaczenie Metryki Litewskiej, „Archeion” 80: 1986, s. 121-182.

${ }^{4}$ M.in. A. Kawecka-Gryczowa, Biblioteka ostatniego Jagiellona, Wrodaw 1988; J. Pirożyński, Księżna brunszwicka Zofia Jagiellonka (1522-1575) i jej biblioteka, Kraków 1986; E. Szandorowska, Biblioteka i pracownia introligatorska Braci Wspólnego Zycia w Chetmnie. Próba rekonstrukcji. „Rocznik Biblioteki Narodowej" 9:1973 5. 265-285; J. Trypućko, Próba rekonstrukcji bibliotekikolegium jezuickiego w Braniewie, wywiezionej w roku 1626 do Szwecji [w:] Dawna książka i kultura, Warszawa 1975, s. 207-220.

${ }^{5} \mathrm{P}$. Bańkowski, Rękopisy rewindykowane przez Polskę z ZSRR na podstawie traktatu ryskiego iich dotychczasowe opracowania, Kraków 1937; prace magisterskie w IBi|N UW: M. Dybaczewska, Dzieje księgozbioru Załuskich po wywiezieniu go z Warszawy, 1967; E. Węgrzyn, Biblioteka Załuskich w świetle opinii wspótczesnych i potomnych, 1978.

${ }^{6}$ P. Bańkowski, dz.cyt. s. 23-28; K. Estreicher, Załuscy. Bibliografia odnosząca się do Załuskich z wieku XVII i XVIII. Odbitka z 34 tomu Bibliografii Polskiej, Kraków 1952, s. 300-301; M. Łodyński, Z dziejów „Biblioteki Rzeczypospolitej Załuskich zwanej” w latach 1785-1794, Warszawa 1935, s. 53; R. Minzloff, Catalogue des publications de la Biblioteque Imperiale de Saint-Petersburg, 1861, s.XLII-LI.

${ }^{7}$ A. Kawecka-Gryczowa, Biblioteka Narodowa w Warszawie, Warszawa 1934, s. 13-14.

${ }^{8}$ K. Buczek, Przyczynek do historii Biblioteki Załuskich, "Przegląd Biblioteczny" 1933, s. 79-84; K. Estreicher, dz. cyt.; A. Kawecka-Gryczowa, dz. cyt., 5. 16-17; H. Juszczakowska, Z badań nad polskimi ksiegozbiorami historycznymi, z. 2, Warszawa 1976, s. 51-55; M. Łodyński, Fragmenta Zalusciana, „Przegląd Biblioteczny" 1938, z. 4, s. 265-268; S. Turowski, Prace Józefa Andrzeja Zaiuskiego w niewoli moskiewskiej, "Sprawozdania Akademii Umiejętności" 1914 nr 5, s. 9.

${ }^{9}$ Listy Andrzeja Stanisława Załuskiego do Józefa Andrzeja Załuskiego z dn. 3 V 1740, $6 \mathrm{~V}$ i 31 VII 1741, 5 XII 1742, 17 IV 1747, 10 I 1748 i 6 VIII 1755, rps. BN sygn. III $3240,3241,3242,3247$, 3248,3255 ( $w$ większości przedrukowane przez M. Kodyńskiego w pracy Biblioteka Rzplitej Załuskich zwana na tle ówczesnych bibliotek zagranicznych, [w:] $Z$ dziejów książki i bibliotek $w$ Warszawie, Warszawa 1961); "Neue Zeitungen von gelehrten Sachen" 1747, s. 691-692; J.D. Janocki, Bibliographia Zalusciana, Berdyczów-Warszawa 1763-1766, s. 246; tenże, Nachricht von denen in der Hochgraeflich Zaluskischen Bibliothek sich befindeden raren Buechern, t. 1 5. 6; F.M. Sobieszczański, Nota wlasnoręczna biskupa Załuskiego podana królowi Stanisławowi Augustowi. "Biblioteka Warszawska” 1848, t. 2, s. 570-572.

${ }^{10}$ Oprócz przytoczonych w przypisach 6-8: E. Brańska, Przyczynki do dziejów Biblioteki Załuskich w Warszawie ijej założycieli [w:] Z badańn nad polskimi księgozbiorami historycznymi, z. 5. Warszawa 1981, s. 83, 95; J. Keckówna, Bibliotheca poetarum polonorum Józefa Andrzeja Załuskiego, „Biuletyn Instytutu Bibliograficznego", 1960, t. 6 nr 4, s. 6-11; M. Manteufflowa, Księgozbiór Józefa Załuskiego w Lotaryngii i jego droga do Polski, „Rocznik Biblioteki Narodowej” 2:1966, s. 348.

${ }^{11}$ Biblioteka Narodowa. Katalog rękopisów. Seria 2, t. 2. Opr. B.S. Kupść, K. Muszyńska, Warszawa 1980, s. 234, 276; J. Keckówna, dz. cyt., s. 9-11; M. Manteufflowa, dz. cyt., s. 348, 354.

${ }^{12}$ R. Minzloff, dz. cyt., s. 5-6; K. i S. Estreicherowie, Bibliografia polska, t. 1 s. LV, t. 14, s. 86, t. 34 s. 240-241; J. Rudnicka, Bibliografia katalogów ksieggarskich w XVIII w. Warszawa 1975, s. 46-48; W. Tyszkowski, Polskie katalogi księgarskie z XVIII w zbiorach Biblioteki Ossolineum, "Ze skarbca kultury" 1986 z. 42, s. 35-92.

${ }^{13}$ M. Manteufflowa, Gospodarka dubletami w Bibliotece Zaluskich, „Roczniki Biblioteczne” 1960, z. 1/2, s. 71.

${ }^{14}$ Catalogus librorum duplicatorum Bibliothecae Publicae Zaluscianae, Warszawa 1762. Katalog ten, opisany w ostatnim tomie Bibliografii Estreichera (t. 34, s. 241, gdzie omyłkowo określono jego format $4^{\circ}$ zamiast $8^{\circ}$ ) przez ćwierć wieku zaginiony (por. M. Manteufflowa, dz. cyt. 5. 71) został ostatnio odnaleziony i po-zabiegach konserwatorskich - udostępniony badaczom (list mgr Ewy Zwinogrodzkiej, kierownika Oddziału Starych Druków BJ z dn. 22 VII 1987 r.). 
${ }^{15}$ Omawiane egzemplarze zostały $w$ wieku dziewiętnastym ozdobnie oprawnione i umieszczone $w$ specjalnej szafie z publikacjami Biblioteki Cesarskiej. Obecnie szafa ta stoi w sali ksiegoznawstwa (Zal Bibliotekowiedenija).

${ }^{16}$ Imperatorskaja Publicznaja Biblioteka za sto let 1814-1914. St.Petersburg 1914, s. 14, 119, 167, 260. Cyt. za: Dokumenty dotyczące akcji delegacji polskiej w komisjach mieszanych rewakuacyjnej $i$ specjalnej w Moskwie, z. 8, Warszawa 1923, s. 166.

${ }^{17}$ B.S. Kupść, Polonica rẹkopiśmienne w Bibliotece im. Sałtykowa-Szczedrina, „Przegląd Biblioteczny" 1958, z. 1, s. 46-54; tenże, Korespondencja Załuskich jako źródło do dziejów kultury polskiej wieku Oświecenia, "Roczniki Biblioteczne" 1961, s. 231-252.

${ }^{18}$ A catalogue of the libraries of...Luke Schaub.... London [1760], sygn. $282045792 ;$ Bibliothecae Grinnerianae pars posterior.., b.m.w. [XVIII w.], sygn. 28204 2658; Catalogus Bibliothecae Ludewigianae, b.m.w. 1744, sygn. 92961602.

19 J. Kozłowski, Szkice o dziejach Biblioteki Załuskich, Wrocław i in., 1986, s. 165-179.

20 Zob. m.in. P. Barikowski, Nieznany list dedykacyjny A. Frycza-Modrzewskiego, "Reformacja w Polsce" 6:1934, z. 1, s. 171; P. Buchwald-Pelcowa, Emblematy w drukach polskich i Polski dotyczących XVI-XVIII w. Bibliografia. Wrocław 1981, s. 146, 157; H. Bukowiecki, M. Kostyniuk, R. Figurski, Niektóre starodruki botaniczne w Bibliotece Załuskich [w:] "Studia i Materiały z Dziejów Nauki Polskiej”, ser.B z. 16, 1969 5. 3-14; S. Gaber, Le fonds Zaluski de la bibliotheque publique de Nancy, "Annales de l'Est" 27:1975 ser. 5e, s. 157-165; M. Karpowicz, Sekretne treści warszawskich zabytków, Warszawa 1981, s. 241; A. Kawecka-Gryczowa, Biblioteka..., s. 14; J. Reychman, Orient wkulturze polskiego Oświecenia, Wroclaw i in. 1964, s. 86-87.

21 „Polnischer Buechersaal”, Wroctaw 1756, z. 1, rozdz. 3; "Kurier Polski" 31 X 1759, Add tament do gazet nr 44; "Wiadomości Uprzywilejowane Warszawskie” 14 | 1761, suplement; tamze, 21 IX 1763, suplement. Na kradzieże książek utyskiwał J.D. Janocki, Nachricht..., t. 3, s. 113, 120, 135.

22 K. Estreicher, Załuscy..., s. 302-303; H. Juszczakowska, dz. cyt., s. $35-76$ (kartoteki proweniencji podobne do opisanych przez autorke, choć prowadzone nie od tak dawna i nie tak systematycznie, znajdują się tez w bibliotekach Narodowej i Ossolineum); R. Kotula, Wlaściciele rękopisów i starodruków zbiorów wielkopolskich Z.Czarneckiego, Lwów 1929, 5. $42-45$ (notuje 25 pozycji z Biblioteki Załuskich); Z. Wiśniowska, Katalog druków Biblioteki-Muzeum Zamkuw Łańcucie, Łańcut 1974 (11 poz.); Katalog starych druków Biblioteki Publicznej m.st. Warszawy, cz. 2; Polonica XVI wieku, opr. A. Kawecka-Gryczowa, Warszawa 1957 (12 poz.); Katalog starych druków Biblioteki Publicznej m.st. Warszawy. Polonica XVII wieku. Opr. J. Rudnicka, Warszawa 1976 (12 poz.); Katalog starych druków Biblioteki Zakładu Narodowego im. Ossolińskich, opr. M. Bohonos, Wroclaw i in. 1965 (3 poz.); Katalog inkunabulów Bibl. Zakładu im. Ossolińskich we Wroclawiu. Na podstawie not K. Piekarskiego opr. A. Kawecka-Gryczowa, Wroclaw 1956 (1 poz.). Warto tu dodać, że w XVIII w. wiele książek fundacji Załuskich znalazło się w księgozbiorze Ignacego Krasickiego (część tego ksieggozbioru, wraz z dziełami z Książnicy Warszawskiej, jest do dziś w bibliotece kolegiaty lowickiej). Ostatnio w Bibliołece Stowarzyszenia Historyków Sztuki wśród darów książkowych prof. Czeslawa Krassowskiego prof. Jerzy Dobrzycki napotkal dzieło z pieczątka IA ZALUSKI: Johanna Wallisa, Geometriae Professoris Saviliani in Celeberrime Academia Oxoniensis, 1. 1-2, Oxford 1656-1657.

${ }^{23}$ Katalog z roku 1748: P. Bańkowski, Rękopisy..., 5. 24; K. Estreicher, Załuscy..., s. 250; A. Iwanowska, M.A. Troc a początki Biblioteki Załuskich, "Kwartalnik Historii Nauki i Techniki” $34: 1989$ nr 4, s. 879-881. - Katalog z roku 1757: P. Bańkowski, dz. cyt., s. 25; K. Estreicher, dz. cyt., s. 249 ; A. Iwanowska, dz. cyt., s. 881-882; J. Lewański, Polskie przeklady J.B. Marina, Wroclaw 1974, 5. 21-22; S. Turowski, Pierwsza wielka bibliografia polska ("Bibliotheca polona magna universalis” J.A. Załuskiego), "Czas" 66:1913 nr 65. Katalog z roku 1757 nosil w Petersburgu sygnature R.F. XVill 59 i liczyl 2 t. o łącznej objętości 1287 s. (kartoteka zniszczonych rękopisów BN).

${ }^{24}$ M. Manteufflowa, Księgozbiór..., s. 348.

${ }^{25}$ Dokumenty dotyczące akcji delegacji polskiej... s. 166 mówią tylko ogólnie, powołując się na książkę pt. Imperatorskaja.. (s. 66) o inwentarzu rękopisów, sporządzonym przed rokiem 1811.

${ }^{26}$ Biblioteka. PAN w Krakowie sygn. 290; BJ sygn. 554; B Ossol. sygn. 1349. J. Korzeniowski, Zapiski z rẹkopisów Cesarskiej Biblioteki Pubilcznej in Petersburgu i inilycti bibliotek petersburskich, 
Kraków 1910 (Archiwum do Dziejów Literatury i Oświaty w Polsce, t. 11) s. XVIII podal, że odpisy znajdowaly się w bibliotekach: Jagielloniskiej, TPN w Poznaniu, Ordynacji Krasińskich w Warszawie i Fundacji Baworowskich we Lwowie.

${ }^{27}$ Imperatorskaja..., s. 66; P. Bańkowski, dz. cyt., s. 31-34; A. Halban [A. Blumenstock], Wiadomość - rękopisach prawno-historycznych Biblioteki Cesarskiej w Petersburgu. Sprawozdanie z poszukiwań. "Archiwum Komisji Historycznej Akademii Umiejętności" t. 6 (1891) s. 382-383; Dokumenty..., s. 79; J. Korzeniowski, Zapiski..., s. XVI-XVII.

${ }^{28}$ A. Brueckner, rec. z książki J. Korzeniowskiego Zapiski... "Pamiętnik Literacki” 1911, s. 573-588; B.A. Dorn, Morgenlaendische Handschriften der Kaiserlichen Offentlichen Bibliothek zu St. Petersburg, St. Petersburg 1865; J.Bonnet, Recherches sur les manuscrits francais de la Bibliotheque Imperiale de St. Petersburg, "Russkij Bibliofil" 1:1911 nr 1 s. $57-62$, nr 2 s. 72-76, nr 3 s. 75-86, nr 4 s. 55-60, nr 6 s. $61-71$, nr 7 s. 48-61, nr 8 s. 44-54; 2:1912 nr 1 s. 61-71; W.A. Maciejowski, Rękopisma Biblioteki Cesarskiej w Petersburgu, „Biblioteka Warszawska” 1843, t. IV, s. 771-772; K. Sochaniewicz, Aẹkopisy czeskie w kolekcji Zaluskich, "Przewodnik Bibliograficzny" 1926 nr 6 s. 265-267; P.Z. Thompson, Biography of a Library. The Western European Manuscript Collection of Peter P. Dubrovskij in Leningrad, "Journal of Library History" 19:1984.

${ }^{29}$ Biblioteka Narodowa. Katalog rękopisów... s. 18-22.

${ }^{30}$ Biblioteka Narodowa: listy J.A. Załuskiego - sygn. III 3224-3269, listy J.D. Janockiego - sygn. III 3275; B S-Sz. Archiw Załuskich, mikr. BN: listy J.A. Zaluskiego (mikr. 15997), J.D. Janockiego (mikr. 15996, 16002). Warto tu dodać, że 14 rękopisów Biblioteki Zaluskich wymienia Janoćki w pięciu listach do Adama Naruszewicza z 1781 r. Listy te zostały przedrukowane w książce Janockiego pt. Janociana.... t. 3, wyd. S.B. Linde, Warszawa 1819, s. XXXVIII-XLIV.

${ }^{31}$ B S-Sz., sygn. F. 120, zespół Byczkowych (m.in. listy do A.F. Byczkowa: E.K. Czapskiego i K. Krasickiego); Petersburski Oddział Akademii Nauk ZSRR, F. 764 op. 2 (m. in. listy do A.F. Byczkowa: J. Baudoina de Courtney, A. Bruecknera, A. Pawińskiego, S. Ptaszyckiego, W. Spasowicza i T. Wierzbowskiego). Por. J. Róziewicz, Listy A. Bielowskiego do A. Byczkowa, "Kwartalnik Historii Nauki i Techniki” $1984 \mathrm{nr} 2$, s. 435-443. - Dla omawianego tematu interesujący jest rps. B S-Sz. sygn, F. $120 \mathrm{op} .1 \mathrm{nr}$ 2126, pismo Stanislawa Ptaszyckiego do iwana Afanasjewa Byczkowa, w którym polski uczony przedstawia, jak rękopisy Zaluskich trafity nad Newę, a także opisuje z autopsji niektóre pozycje (wg informacji Siergieja G. Zemajtisa z XII 1990. S.G. Zemajtis przygotowuje obecnie do druku katalog polskich rękopisów Biblioteki im. Saltykowa-Szczedrina). - A.F. Byczkow był dyrektorem Biblioteki w I. 1882-1899. Oprócz niego placówką tą kierowali kolejno A.M. Olenin (1814-1843), D.P. Buturlin (18431849), M.A. Korf (1849-1861), I.D. Delanow, N.K. Szydler (1899-1901), D.F. Kobenko (1902-1913). Wstępne poszukiwania listów wymienionych bibliotekarzy w zbiorach petersburskich Archiwum Akademii i Biblioteki im. Saltykowa-Szczedrina dały skromne wyniki.

32 Archiwum BN: Korespondencja w sprawie wypożyczeń druków i rękopisów 1932-1938 (teczka 103); Korespondencja w sprawach informacji o zbiorach i kwerend 1931-1935 (teczka 104); Sprawozdania okresowe działów Bibliateki 1938 - IV 1939 (teczki 128-140); bruliony sprawozdań z pracy Działu Rękopisów 1936-1940 (teczka 163); Biblioteka Kórnicka: Materiały S. Bodniaka z okresu pracy w Bibliotece Narodowej 1939-1944, rps. sygn. 11575.

${ }^{33}$ J.A. Zaluski, Corpus scriptorum rerum polonicarum ineditorum [w:] Programma Litterarium...; tenże, Contenta collectionis scriptorum ecclesiasticorum Poloniae ineditorum vel rarissime obviorum [w:] Conspectus Novae Collectionis Legum Ecclesiasticarum Poloniae... Warszawa 1744 (34 rękopisy); „Kurier Polski” 17 VI 1754 nr 52 (prośba o pomoc w skompletowaniu Acta Tomiciana).

34 J. Kozlowski, dz. cyt., s. 122 (memorial W. Mitzlera de Kolof). Por.' też M. Łodyński, Z dziejów „Biblioteki Rzeczypospolitej...", s. 98, 11-113 (memorial O. Kopczyńskiego).

35 J. Jarzęcka, J. Kozłowski, Biblioteka Załuskich w świetle "Neuer Zeitungen von gelehrten Sachen" (1726-1767), "Kwartalnik Historii Nauki i Techniki” 28:1978, s. 311; J. Mayer, Zalusciana w "Bibliotheque Germanique" (Amsterdam 1720-1741) i Nouvelle Bibliotheque Germanique" (Amsterdam 1746-1790), "Rocznik Biblioteki Narodowej" 14:1970, s. 197-199; J.D. Janocki, Excerptum Polonicae litteraturae huius atque superioris aetatis, cz. 1, Wrodaw 1764, fragm. LXXV; J. Bernoulli, Reisen durch Brandenburg, Pommern, Preussen, Curland, Russland und Polen in den Jahren 1777 und 1778, Lipsk 1779-1780, cyt. za polskim przekladem Podróż po Polsce 1778 [w:] Polska stanisławowska w oczach cudzoziemców, wyd. W. Zawadzki, t, 1, Warszawa 1963, s. 339. 
36 J. Kozlowski, dz. cyt. s. 165-179; O. Kopczyński, Uklad gramatyki dla szkól narodowych..., Warszawa 1785, 5. 29-30, cyt. za I. Stasiewicz-Jasiukowa, Onufny Kopczyński, współpracownik Komisji Edukacji Narodowej, Wroclaw 1987, s. 22.

${ }^{37}$ P. Bańkowski, Rękopisy rewindykowane..., s. 35; tenże, rec. ksiażki A. De Laborde, Les principaux manuscrits a peintures, „Przegląd Biblioteczny” 11:1937, z. 3, s. 190-197; Biblioteka Narodowa. Katalog rękopisów. ser. 2 t. 2; A. Halban [A. Blumenstock], Wiadomość...; E. Chwalewik, dz. cyt., s. 39-43; M. Dybaczewska, dz. cyt.; J. Korzeniowski, dz. cyt., s. XIII-XIV; J. Kuntze, Uklady o zwrot Biblioteki Zaluskich, Lwów 1920, s. 29; Dokumenty..., s. 81-82, 91-100. - Rękopisy Załuskich cytuje też m.in. J. Lelewel, Bibliograficznych ksiag dwoje, t. 2, Wilno 1926, s. 81-82, 345.

${ }^{38}$ P. Bańkowski, Rękopisy rewindykowane na podstawie traktatu ryskiego jako warsztat pracy naukowejprzed wojna, "Przegląd Biblioteczny” 1948 z. 1/2, s. 101-118; J. Mazur, Udostępnianie zbiorów rękopiśmiennych w Bibliotece Narodowej w I. 1928-1984, "Biuletyn Informacyjny Biblioteki Narodowej" 1985 nr 3-4; tenże. Prace w zasobie rękopisów Biblioteki Narodowej w l. 1939-1945 (ochrona, zabezpieczenie i działalność informacyjno-naukowa) [w:] Rocznik Naukowo-Dydaktyczny WSP w Krakowie, 1990 , z. 135. Prace Bibliotekoznawcze V, s. 57-74; tenże, Dziaialność informacyjna Działu Rękopisów Biblioteki Narodowej wl. 1928-1939 „Studia Bibliologiczne" 3:1990, Prace Naukowe Uniwersytetu Śląskiego, s. 41-53-Rękopisy Zaluskich cytują i omawiają m.in. P. Bohdziewicz, Studia z dziejów sztuki polskiej okresu baroku irokoka, Lublin 1973; J. Lewański, Polskie przeklady J.B. Marina, Wroclaw 1974; K. Muszyńska, Autografy i odpisy dziet Dugosza w zbiorach Biblioteki Narodowej, "Rocznik Biblioteki Narodowej" 17/18:1981/1982, s. 404-406; W.J. Stankiewicz, The accomplished Senator of Laurentius Goslicius, Wallau 1946, s. 40; J. Wiesiolowski. Kolekcje historyczne w Polsce średniowiecznej XIV-XV W., Wrocław 1967, s. 164-165.

39 Okres Biblioteki Załuskich: Notaty T. Czackiego w Bibliotece Kórnickiej, m.in. sygn. 756; J. Kozłowski, dz, cyt., s. 172-175. - Okres petersburski: S. Młodecki, $Z$ badań nad zbiorem M.Malinowskiego w Bibliotece Kórnickiej, „Pamiętnik Biblioteki Kórnickiej” 7:1959, s. 219-240; J. Maternicki, Warszawskie środowisko historyczne 1832-1869, Warszawa 1970, s. 71; P. Bańkowski, Rękopisy..., s. 40; K. Estreicher, Zaluscy..., s. 237-238. Okres po rewindykacji: Notatki o rękopisach [w:] Materiahy S. Bodniaka z okresu pracy w Bibliotece Narodowej 1939-1944, Bibl, Kórnicka sygn. 11575; Z, Kalisz, O dzialalności bibliotekarskiej i naukowej S. Bodniaka, „Pamiętnik Biblioteki Kórnickiej" 19:1982, s. 161-201; J. Grabowiecki, O nieopublikowanej monografii Marcina Kromera pióra Stanislawa Bodniaka, „Prace Naukowe Wyższej Szkoly Pedagogicznej w Częstochowie. Filologia Polska, Historia i Teoria Literatury", 1985, z. 1, s. 9-19; E. Brańska, A.S. Załuski a reforma Uniwersytetu Krakowskiego i innych wyższych uczelni w Polsce Weltinów. Przyczynkiźródłowe. „Kwartalnik Historii Nauki i Techniki” 28:1983 nr 1, s. 177; M. Hornowska, Materialy źródłowe i warsztatowe do ksiażki o bibliotekach średniowiecznych (klasztory, kolegia i parafie) w Polsce. Notatki z Biblioteki im. Saltykowa-Szczedrina, rps. Bibl. Nar. sygn. IV 10427/1-3; P. Bańkowski, Straty Biblioteki Narodowej w zakresie rękopiśmiennych źródet historycznych [w:] Straty bibliotek $i$ archiwów warszawskich $w$ zakresie rękopiśmiennych źródel historycznych, Warszawa 1955, s. 13. - Materiały warsztatowe uczonych, którzy pracowali nad manuskryptami Załuskich można odszukać dzięki przewodnikom po archiwach, ksiażce D. Kamolowej i K. Muszyńskiej pt. Zbiory rękopisów w bibliotekach i muzeach w Polsce, Warszawa 1988 oraz dzięki spisowi spuścizn historyków (masz. Archiwum PAN, opr. H. Dymnicka-Wołoszyńska i S. Chankowski). Podobną kwerendę możnaby przeprowadzić wśród materiałów warsztatowych dziewiętnastowiecznych historyków rosyjskich.

${ }^{40}$ A. Naruszewicz, Korespondencja 1762-1796,opr. J. Platt, Wrocław 1959; J. Krzyżanowski do L. Kamykowskiego, 27 II 1937, rps. Bibl. Ossolineum sygn. 12471/1-2.

${ }^{41}$ Dla okresu Biblioteki Zaluskich zob. m.in. S. Grzybowski, Teki Naruszewicza, Wroclaw 1960, s. 30-32; I. Treichel, $Z$ dziejów jednego rękopisu. Notatka bibliograficzna. "Przegląd Biblioteczny" 21:1953, z. 3, 5. 259-264 oraz K. Nizio, Polska w obszernych wiadomościach swoich skrócona - rękapisy dzieła J.A. Zaluskiego, „Pamiętnik Biblioteki Kórnickiej” 1986, z. 21, s. 137-147; W. Semkowicz, Przewodnik po zbiorach wilanowskich, Warszawa 1961, s. 29 (dotyczy rękopisu Świętosława Orzeiskiego), Interregni Poloniae Libri...; is. 47 (dotyczy diariuszy sejmowych). - Dla okresu petersburskiego zob. m.in. rps. Les amours royales, Bibliotheque Municipale de Bordeaux, sygn. 1098 fol. 5, 55, 97, 163, 191, 237. Jest to 6 odpisów z rękopisów Biblioteki Zaluskich, sporządzonych w Cesarskiej Bibliotece Publicznej. Zawieraja one glównie opisy milostek Ludwika XIV. Odpisy te zostały podarowane bibliotece w Boredeaux w roku 1886 przez Houyn'a de Tranchere (list N. Massias, conservateur en chef z dn. 25 II 1985). Por. też Catalogue general des manuscrits de bibliotheque publique de France, t. 23, Paryź 1894. - Dla okresu po rewindykacji, m.in. odpisy S. Bodniaka, cyt. w przyp. 39. 
${ }^{42}$ Okres Biblioteki Załuskich. Zob. m.in. J.Kozłowski, Szkice..., s. 165-179; J. Kurkowski, Dzialalność Wawrzyńca Mitzlera de Kolof w Rzeczypospolitej jako redaktora czasopism i wydawcy źródet historycznych, "Studia i Materiały z Dziejów Nauki Polskiej”, ser. I, z. 4, 1990, s. 5-84. - Okres petersburski. $\mathrm{Na}$ podstawie rękopisów Biblioteki Warszawskiej F. Kulczycki oglosil dziennik podróży Sebastiana Gawareckiego, guwernanta braci Marka i Jana Sobieskich (Pisma do wieku i spraw Jana Sobieskiego, Kraków 1880, t. 1, cz. 1, s. 38-131, Acta Historica Res Gestas Poloniae Illustrantia..., vol. 2, a A. Małecki Kronikę Baszka ("Kwartalnik Historyczny" 1894, z. 1, s. 1-23) - Okres po rewindykacji. Z rękopisów Załuskich wydano m.in. Liber chamorumW. Nekandy Trepki, Wrocław 1963, Pamiętniki Paska, Wroclaw 1979 i sztambuch J.A. Załuskiego, "Silva Rerum" 1928 z. 10/12, s. 147-154. O wydaniach zachowanych po roku 1944 manuskryptów informujje Katalog rękopisów Biblioteki Narodowej, opr. B.S. Kupść, K Muszyńska, Warszawa 1980, a także katalogi ocalałych rękopisów rewindykowanych (w maszynopisie).

${ }^{43}$ S. Grzybowski, Teki Naruszewicza, Wrocław 1960, s. 31-32. Warto tu dodać, że w roku 1792 Linde stwierdził ubytki w rękopisach Biblioteki Załuskich, zob. Dokumenty dotyczące akcji..., s. 78.

${ }^{44}$ W tych latach, jak można sądzić, opuścił zbiory Załuskich wspomniany Dziennik podróży Sebastiana Gawareckiego; rękopis ten w XIX w. znalazł się w kolekcji Franciszka Kulczyckiego, a później w Archiwum Potockich. Zob. W. Semkowicz, Przewodnik po zbiorze rękopisów wilanowskich, Warszawa 1961 , s. 225-226.

45 P. Bańkowski, Rękopisy rewindykowane..., s. 14. Por, też S. Ptaszycki, Krótka wiadomość o rękopisach Biblioteki Szczorskiej [w:] Ksią̇ka zbiorowa poświęcona pamięci A.Mickiewicza, Warszawa 1899; Slownik pracowników ksiażki polskiej, Warszawa-Łódź 1972, s. 122-124.

${ }^{46}$ P. Bańkowski, dz. cyt., s. 14-15; tenże, Archiwum Stanislawa Augusta, Warszawa 1958, s. 91; J. Rudnicka, Losy rękopisów z Biblioteki króla Stanisława Augusta, "Kronika Warszawy” 1980, z. 1, s. 131; Slownik..., s. 135-136.

${ }^{47}$ P. Bańkowski, dz. cyt., s. 17. Por. też F. Pohorecki, Teki i zbiory Żegoły Onacewicza, Pamiętnik VI Zjazdu Historyków Polskich 1935, s. 414-424; Słownik pracowników książki polskiej. Suplement. Warszawa-Łódź 1986, s. 159-160. Spuścizna Z. Onacewicza znajduje się w petersburskim Instytucie Literatury Rosyjskiej (Puszkinskij Dom) i po kilkuletniej przerwie ma zostać udostępniona w roku 1992. Por. też N. Iwaszkiewicz, Bezcenne polonica, "Literatura" 1979, nr 51-52.

${ }^{48}$ P. Bańkowski, Rękopisy..., s. 15, 8.S. Kupść, Polonica rękopiśmienne w Bibliotece Publicznej im. Saltykowa-Szczedrina i w niektórych innych zbiorach w Leningradzie, "Przeglad Biblioteczny" 1958, z. 1, 5. 46-54.

${ }^{49}$ Dokumenty dotyczące akcji.., s.59.

${ }^{50}$ B.S. Kupść, K. Muszyńska, Wstęp [w:] Biblioteka Narodowa. Katalog rękopisów. ser. 2, t. 2, s. 7.

51 tamże, s. 9-12.

52 Literatura przedmiotu w: dz. cyt., s. 18-22. Zamieszczoną tu listę uzupehniają też prace zarejestrowane w: M. Jasińska, Bibliografia materiałów publikowanych $w$ drukach zwartych i periodykach dotyczących ochrony zbiorów archiwalnych, bibliotecznych i muzealnych w Warszawie $w$ okresie okupacji [w:] Walka o dabra kultury, Warszawa 1939-1945, t. 1-2, Warszawa 1970, s. 571-592; H. Kozerska, W. Stummer, Inwentarz spuścizny rękopiśmiennej A. Lewaka w Bibliotece Uniwersyteckiej w Warszawie, "Roczniki Biblioteczne" 1964 z. 3/4, s. 375-392.

${ }^{53}$ F. Pułaski, Opis 815 rękopisów Biblioteki Ordynacji Krasińskich, Warszawa 1915 (poz. 130, $544-546,611)$.

${ }^{54}$ m.in. pontytikal Erazma Ciołka, K. Estreicher, Załuscy..., s. 302.

${ }^{55} \mathrm{~m}$.in. rękopis sygn. 3584.

${ }^{56} \mathrm{~m}$.in. rękopis sygn. 161.

${ }^{57}$ Biblioteka Narodowa. Katalog rękopisów..., 5. 13.

58 Spis sygnatur (ok. 200) w Supplementum ad Sigla codicum manuscriptorum qui olim in Bibliotheca Publica Leninopolitana.... Kraków 1928, s. 6. 